\title{
Effectiveness of tes-tris or tris association with low density lipoprotein on in vitro longevity of refrigerated buffalo semen
}

\author{
[Eficácia da associação TES-TRIS ou TRIS com lipoproteína de baixa densidade sobre a \\ longevidade in vitro de sêmen refrigerado de búfalos] \\ J. Almeida, M.F. Brito, V.A.B. Becerra, B.P.Neves, P.A. Auler, \\ J.P. Hadad, M. Henry
}

Escola de Veterinária - Universidade Federal de Minas Gerais - Belo Horizonte, MG

\begin{abstract}
This study investigated in vitro the efficacy of four different extenders (TES-TRIS and TRIS with LDL low-density lipoprotein at concentrations of 10 or $5 \%$ ) on the longevity of buffalo sperm in the refrigeration process at $5^{\circ} \mathrm{C}$. Sperm motility was assessed every 24 hours up to 72 hours of incubation using computer assisted sperm analysis and sperm membrane integrity was examined by the hypoosmotic test (HOST) at T1, T24, T48 and T72 hours. Eleven buffaloes (1 ejaculate per buffalo) of the Murrah breed were used, ranging in age from 4 to 5 years. Immediately after collection, each ejaculate was fractionated into 4 aliquots, and each aliquot was diluted in one of four diluents to obtain $50 \times 10^{6} \mathrm{SPTZ} / \mathrm{mL}$. The samples were packed in $0.5 \mathrm{~mL}$ straws and refrigerated $\left(-0.25^{\circ} \mathrm{C} / \mathrm{min}\right)$ to $5^{\circ} \mathrm{C}$ and maintained at this temperature until evaluation. Prior to evaluation the samples were heated at $37^{\circ} \mathrm{C}$ for 30 seconds. The statistical package used for analysis was STATA 12.0 "Statistical Analysis Software" and means were compared by the Friedman test $(\mathrm{P}<0.05)$. The results of sperm kinetics and HOST indicate that the TRIS diluent with 10\% LDL could be a promising alternative for semen refrigeration at $5^{\circ} \mathrm{C}$, to be used in conventional and fixed time artificial insemination.
\end{abstract}

Keywords: sperm motility, low density lipoprotein, hypoosmotic test

\section{RESUMO}

Este estudo investigou in vitro a eficácia de quatro diferentes extensores (TES-TRIS e TRIS com lipoproteína de baixa densidade - LDL, nas concentrações de 10 ou 5\%) sobre a longevidade espermática de búfalos no processo de refrigeração a $5^{\circ} \mathrm{C}$. A motilidade espermática foi avaliada a cada 24 horas até 72 horas de incubação, por sistema computadorizado "CASA", e a integridade de membrana espermática foi examinada pelo teste hiposmótico (HOST) em T1, T24, T48 e T72 horas. Foram utilizados 11 búfalos (um ejaculado por búfalo) da raça Murrah, com idade variando de quatro a cinco anos. Imediatamente após a coleta, cada ejaculado foi fracionado em quatro alíquotas, e cada

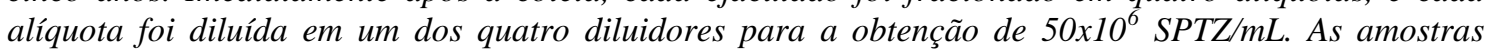
foram envasadas em palhetas de $0,5 \mathrm{~mL}$, refrigeradas $\left(-0,25^{\circ} \mathrm{C} /\right.$ minuto) até $5^{\circ} \mathrm{C}$ e mantidas nessa temperatura até a avaliação. Previamente à avaliação, as amostras foram aquecidas a $37^{\circ} \mathrm{C}$ por 30 segundos. O pacote estatístico utilizado para as análises foi o STATA 12.0 "Statistical Analysis Software", e as médias foram comparadas pelo teste de Friedman $(P<0,05)$. Os resultados de cinética e HOST até o tempo de 48 horas indicam que o diluidor TRIS com 10\% LDL seria uma alternativa promissora para a refrigeração do sêmen a $5^{\circ} \mathrm{C}$, a ser utilizado na inseminação artificial e na inseminação artificial em tempo fixo.

Palavras-chave: motilidade espermática, lipoproteína de baixa densidade, teste hiposmótico

Recebido em 30 de agosto de 2018

Aceito em 1 de outubro de 2019

E-mail: jacialmeida01@yahoo.com.br 


\section{INTRODUCTION}

In Brazil, several reproductive biotechniques such as artificial insemination (AI), artificial insemination at fixed time (FTAI), embryo transfer (ET), and in vitro embryo production (IVEP), have been used in order to accelerate genetic gains or reduce the interval between generations. However, only $1 \%$ of buffalo females are artificially inseminated (Instituto..., 2013). The low use of AI in the species is attributed to the difficulty of detecting estrus associated to low sperm longevity of semen after thawing, the short period of annual physiological reproductive activity in buffaloes, the low regional availability of commercial semen, and to the restricted knowledge of the reproductive management of the species.

AI is mainly based on the use of frozen semen. However, the process of freezing/thawing causes different kinds of damage to the sperm cells (Holt, 2000). These effects, among others, are characterized by the destabilization of the plasmatic membrane and consequent elevation of the intracellular calcium concentration, similar to what occurs during sperm capacitation, which may cause irreparable damage (Watson, 1995). Considering that the capacitated sperm and/or with reacted acrosome has a limited life span, this may result in lower fertility if these changes occur at an inadequate moment (Yanagimachi, 1994). Even with more enhanced conservation techniques, only around half the sperm population survives the freezing and thawing processes (Watson, 1995). In order to decrease this problem, research has been done evaluating the preservation of refrigerated semen in bovines (Borges-Silva et al., 2015) and buffaloes (Almeida et al., 2015, 2016, 2017).

The main advantage of using refrigerated semen is the reduction of cryoinjuries to spermatozoon in the initial preservation phase compared to what happens when the cell is frozen. This characteristic provides greater sperm viability/longevity in the female reproductive organ (Bucker et al., 2009). The authors state that it also provides the reduction of the insemination dose, allowing for the optimization of sires of high genetic merit in AI programs, particularly those that have sperm cells with low freezing resistance. Additionally, the use of refrigerated semen minimizes the costs related to stocking and simplifies the manipulation/use of semen in $\mathrm{AI}$, when compared to frozen semen (Vishwanath, 2003).

Therefore, the aim of the present study was to verify the effects of passive refrigeration on the sperm cells of buffaloes, using TES-TRIS and TRIS diluents with 10 or 5\% LDL in replacement of egg yolk.

\section{MATERIAL AND METHODS}

The study was approved by the Ethics Committee for Animal Use of the Universidade Federal de Minas Gerais (Protocol CEUA UFMG 368/2015), following the ethical principles for experiments with animals. The experiment was conducted at the Centro de Biotecnologia em Bubalinocultura - Fazenda Modelo - Pedro Leopoldo, Minas Gerais State.

Eleven Murrah breed buffaloes, between 4 and 5 years of age, were kept on pasture during the experiment and given mineral salt and water $a d$ libitum. The animals were previously conditioned to semen collection with artificial vagina and were kept on a weekly seminal collection regime during the entire experiment. Collections ( 1 ejaculate per buffalo) were preceded by a fake mount (mount with penis deviation and no collection) to increase sperm concentration. Only ejaculates with motility $\geq 70 \%$, vigor $\geq 3$, spermatic abnormalities $\leq 30 \%$, and at least $700 \times 10^{6} \mathrm{SPTZ} / \mathrm{mL}$, were used.

Two seminal extenders were used, TRIS and TES-TRIS, each with 5 or $10 \%$ of low-density lipoprotein (LDL). LDLs were extracted from fresh eggs following the technique described by Neves et al. (2008).

Immediately after collection, each ejaculate was subjected to analysis of the physical and morphological characteristics, according to CBRA guidelines, (Manual..., 2013). Each ejaculate was fractioned in 4 aliquots, each sample was diluted in one of the extenders to obtain $50 \times 10^{6} \mathrm{SPTZ} / \mathrm{mL}$. Diluted semen was packaged in $0.5 \mathrm{~mL}$ straws, inserted in plastic bags, and submerged in a glass container full of water $(1.4 \mathrm{~L})$ at $27^{\circ} \mathrm{C}$. The vial was then placed in a $5^{\circ} \mathrm{C}$ environment (40 to 60 minutes post seminal collection). Average achieved cooling rate was $-0.25^{\circ} \mathrm{C} /$ minute (from 27 to $5^{\circ} \mathrm{C}$ ). Straws were kept refrigerated at $5^{\circ} \mathrm{C}$ for up to 72 hours. 
Sperm kinetic assessments were performed by computer assisted sperm analysis (Sperm Class Analyzer - $\mathrm{SCA}^{\circledR}$ v.4.0 models). Total motility (TM), progressive motility (PM), curvilinear velocity $(\mathrm{VCL}-\mu \mathrm{m} / \mathrm{s})$, average path velocity (VAP- $\mu \mathrm{m} / \mathrm{s}$ ), straight line velocity (VSL- $\mu \mathrm{m} / \mathrm{s}$ ), linearity (LIN), straightness (STR), oscillation index (WOB), amplitude of lateral head displacement (ALH), and tail beat frequency (TBF) were analysed at 1 (T1, before cooling), 24 (T24), 48 (T48), and 72 hours (T72) post final dilution. According to Farell et al. (1998), the above-mentioned parameters are well related to sperm fertility.

The content of a straw of each treatment was warmed to $37^{\circ} \mathrm{C} / 30$ seconds, placed in a $1.5 \mathrm{~mL}$ Eppendorf $^{\circledR}$ and maintained in a dry bath at $37^{\circ} \mathrm{C} / 5$ minutes before being submitted for analysis. The SCA setup used for buffalo sperm analysis was: particle area (20 to 70 microns $\left.^{2}\right)$, CLS $(10>$ slow $<25 ;>25$ medium $<50$, and fast $>50 \mathrm{microns} / \mathrm{second})$, Progressivity (>70\% STR), Circular ( $<50 \%$ LIN), Points to TS (5) and Connectivity (12). For analysis, a $5 \mu \mathrm{L}$ drop of each sample was placed between a slide and cover slide, previously warmed to and kept at $37^{\circ} \mathrm{C}$ during assessment. Five homogeneous fields with a minimum of 200 sperm cells/field were captured and analysed per sample.

The functional integrity of the sperm plasmatic membrane was evaluated by the hypoosmotic swelling test (HOST) at 1 (T1), 24 (T24), 48 (T48), and 72 hours of incubation (T72). For analysis $50 \mu \mathrm{L}$ of semen was added to $500 \mu \mathrm{L}$ of a hypoosmotic solution, $(121 \mathrm{mOsm} / \mathrm{L}-2.702 \mathrm{~g}$ of fructose $+1.324 \mathrm{~g}$ of sodium citrate) and maintained for 30 minutes in a dry bath at $37^{\circ} \mathrm{C}$. Thereafter the solution was fixed in $200 \mu \mathrm{L}$ buffered saline formaldehyde for posterior analysis. Two hundred sperm cells were assessed using a phase contrast microscope (x1000).

The experimental design included 4 extenders, 4 evaluation times and 11 sires, configuring a block system, characterizing three variation sources (extender, refrigeration time, and bull). Considering that the experiment followed a random block design with repetitive measures in each treatment and animal, the Friedman test was used with pairwise comparison. The statistical package used was STATA 12.0 Statistical Analysis Software (Stata..., 2012).

\section{RESULTS AND DISCUSSION}

Ejaculate characteristics immediately postcollection are presented in Table 1. At the first attempt, sperm parameters surpassed the minimum values stipulated for the maintenance of ejaculates to be cooled. This finding indicated the good reproductive health of seminal donors. Using seminal donors submitted to an uninterrupted weekly seminal collection schedule avoided aging the extragonadal sperm reserves and contributed to the maintenance of healthy sperm cells. The good concentration values and the total amount of sperm per ejaculate obtained can be attributed, at least in part, to the fake mount induced before seminal collection. Over excitation may have contributed to a greater sperm output.

Table 1. Characteristics of semen of Murrah buffaloes $(n=11)$ assessed immediately post collection

\begin{tabular}{lccccccc}
\hline Animals & $\begin{array}{c}\text { Volume } \\
(\mathrm{mL})\end{array}$ & $\begin{array}{c}\text { Mass motility } \\
(0-5)\end{array}$ & $\begin{array}{c}\text { Subjective } \\
\text { Mot. }(\%)\end{array}$ & $\begin{array}{c}\text { Vigor } \\
(0-5)\end{array}$ & $\begin{array}{c}\text { Concentration } \\
\left(\mathrm{x} 10^{6} / \mathrm{mL}\right)\end{array}$ & $\begin{array}{c}\text { MD } \\
(\%)\end{array}$ & $\begin{array}{c}\text { TD } \\
(\%)\end{array}$ \\
\hline 1 & 1.4 & 4 & 90 & 3 & 910 & 7.5 & 14.7 \\
2 & 2.0 & 3 & 85 & 3 & 1095 & 6.0 & 11.9 \\
3 & 1.5 & 3 & 80 & 3 & 1060 & 5.0 & 12.8 \\
4 & 3.0 & 3 & 85 & 3 & 1200 & 5.0 & 19.6 \\
5 & 1.2 & 3 & 80 & 3 & 1520 & 6.7 & 13.9 \\
6 & 2.5 & 3 & 90 & 4 & 1305 & 4.8 & 16.1 \\
7 & 2.1 & 4 & 95 & 4 & 1565 & 8.1 & 19.9 \\
8 & 1.7 & 4 & 85 & 3 & 1610 & 6.2 & 13.2 \\
9 & 3.0 & 4 & 90 & 4 & 745 & 7.1 & 15.4 \\
10 & 3.1 & 3 & 90 & 4 & 800 & 9.1 & 19.0 \\
11 & 2.2 & 4 & 95 & 4 & 3250 & 6.7 & 17.9 \\
Average \pm SD & $2.2 \pm 0.7$ & $3.5 \pm 0.5$ & $87.7 \pm 5.2$ & $3.5 \pm 0.5$ & $1369.1 \pm 659.5$ & $6.7 \pm 1.3$ & $15.9 \pm 3.0$ \\
\hline
\end{tabular}

Mot. = Motility; MD = Major defects; TD = Total defects and SD = Standard deviation. 
Sperm motility parameters assessed by CASA are presented in Table 2. At T1, total and progressive motility values were above 90 and $79 \%$, respectively, very close to values obtained by the subjective assessment performed immediately post collection. The lack of difference in sperm motility between extenders at T1 indicated that all extenders fulfilled minimum quality requirements to maintain cells viable. In fact, basic components present in the four mediums have already been used in buffalo for frozen semen (Akhter et al., 2011; Singh et al., 2012 and Almeida et al., 2017) as well as in other species (Neves, 2008). The 5 or $10 \%$ LDL concentration which replaced whole egg yolk of the original extender did not alter sperm quality, at least, at $\mathrm{T} 1$ incubation period.

Table 2. Effects of the different extenders on kinetic parameters of buffalo sperm assessed by computerized analysis (CASA) post dilution (T1 hour - ambient temperature) and post refrigeration to $5^{\circ} \mathrm{C}$ (T24, T48 and T72 hours)

\begin{tabular}{|c|c|c|c|c|c|}
\hline \multirow{3}{*}{ Sperm Parameters } & \multirow{3}{*}{$\begin{array}{c}\text { Time } \\
\text { (hours) }\end{array}$} & \multicolumn{4}{|c|}{ Extenders } \\
\hline & & TES-TRIS $10 \%$ & TES-TRIS $5 \%$ & TRIS & TRIS \\
\hline & & LDL & LDL & $10 \% \mathrm{LDL}$ & $5 \% \mathrm{LDL}$ \\
\hline \multirow{2}{*}{$\mathrm{TM}(\%)$} & 24 & $93.9^{\mathrm{a}}$ & $93.8^{\mathrm{a}}$ & $90.9^{\mathrm{a}}$ & $89.2^{\mathrm{a}}$ \\
\hline & 48 & $89.9^{\mathrm{a}}$ & $92.4^{\mathrm{a}}$ & $88.0^{\mathrm{a}}$ & $87.5^{\mathrm{a}}$ \\
\hline \multirow{3}{*}{$\mathrm{PM}(\%)$} & 72 & $80.0^{\mathrm{a}}$ & $80.2^{\mathrm{a}}$ & $78.4^{\mathrm{ab}}$ & $75.7^{\mathrm{b}}$ \\
\hline & 48 & $66.9^{\mathrm{ab}}$ & $71.3^{\mathrm{a}}$ & $64.0^{\mathrm{ab}}$ & $62.4^{\mathrm{b}}$ \\
\hline & 72 & $55.8^{\mathrm{a}}$ & $55.2^{\mathrm{ab}}$ & $50.4^{\mathrm{bc}}$ & $48.5^{\mathrm{c}}$ \\
\hline \multirow[b]{3}{*}{$\operatorname{VCL}(\mu \mathrm{m} / \mathrm{s})$} & 1 & $103.3^{\mathrm{a}}$ & $88.5^{\mathrm{b}}$ & $98.0^{\mathrm{ab}}$ & $89.0^{\mathrm{b}}$ \\
\hline & 24 & $87.6^{\mathrm{a}}$ & $82.4^{\mathrm{b}}$ & $89.9^{\mathrm{a}}$ & $81.8^{\mathrm{b}}$ \\
\hline & 48 & $63.8^{\mathrm{b}}$ & $82.4^{\mathrm{a}}$ & $89.9^{\mathrm{a}}$ & $81.8^{\mathrm{a}}$ \\
\hline $\mathrm{VAP}(\mu \mathrm{m} / \mathrm{s})$ & 72 & $36.2^{\mathrm{c}}$ & $47.8^{\mathrm{b}}$ & $44.5^{\mathrm{b}}$ & $56.3^{\mathrm{a}}$ \\
\hline \multirow{5}{*}{$\operatorname{VSL}(\mu \mathrm{m} / \mathrm{s})$} & 1 & $43.3^{\mathrm{ab}}$ & $42.8^{\mathrm{ab}}$ & $48.4^{\mathrm{a}}$ & $32.0^{\mathrm{b}}$ \\
\hline & 24 & $41.4^{\mathrm{b}}$ & $41.6^{\mathrm{b}}$ & $53.2^{\mathrm{a}}$ & $32.6^{\mathrm{c}}$ \\
\hline & 48 & $27.5^{\mathrm{c}}$ & $37.4^{\mathrm{b}}$ & $44.2^{\mathrm{a}}$ & $27.9^{c}$ \\
\hline & 72 & $22.9^{c}$ & $31.7^{\mathrm{b}}$ & $39.8^{\mathrm{a}}$ & $21.7^{\mathrm{c}}$ \\
\hline & 1 & $44.3^{\mathrm{b}}$ & $46.0^{\mathrm{b}}$ & $51.1^{\mathrm{a}}$ & $36.5^{\mathrm{c}}$ \\
\hline \multirow{3}{*}{ LIN (\%) } & 24 & $46.7^{\mathrm{b}}$ & $46.6^{\mathrm{b}}$ & $56.2^{\mathrm{a}}$ & $36.9^{c}$ \\
\hline & 48 & $41.1^{\mathrm{c}}$ & $47.8^{\mathrm{b}}$ & $57.4^{\mathrm{a}}$ & $33.2^{\mathrm{d}}$ \\
\hline & 72 & $33.7^{\mathrm{b}}$ & $45.3^{\mathrm{a}}$ & $48.8^{\mathrm{a}}$ & $31.3^{\mathrm{b}}$ \\
\hline \multirow[b]{3}{*}{ STR (\%) } & 1 & $65.9^{\mathrm{a}}$ & $65.8^{\mathrm{a}}$ & $68.8^{\mathrm{a}}$ & $59.5^{\mathrm{b}}$ \\
\hline & 24 & $70.6^{\mathrm{b}}$ & $69.7^{\mathrm{b}}$ & $74.4^{\mathrm{a}}$ & $58.3^{\mathrm{c}}$ \\
\hline & 48 & $63.7^{b}$ & $73.2^{\mathrm{a}}$ & $75.1^{\mathrm{a}}$ & $45.1^{\mathrm{c}}$ \\
\hline \multirow[t]{3}{*}{$\operatorname{ALH}(\mu \mathrm{m})$} & 48 & $3.3^{\mathrm{bc}}$ & $3.7^{\mathrm{c}}$ & $2.6^{\mathrm{a}}$ & $2.9^{\mathrm{ab}}$ \\
\hline & 72 & $3.5^{\mathrm{b}}$ & $3.7^{\mathrm{b}}$ & $2.7^{\mathrm{a}}$ & $3.0^{\mathrm{a}}$ \\
\hline & 1 & $8.4^{\mathrm{b}}$ & $8.5^{\mathrm{b}}$ & $10.0^{\mathrm{a}}$ & $8.9^{\mathrm{b}}$ \\
\hline \multirow{3}{*}{$\mathrm{BCF}(\mathrm{Hz})$} & 24 & $10.2^{\mathrm{ab}}$ & $9.4^{\mathrm{b}}$ & $10.9^{\mathrm{a}}$ & $10.3^{\mathrm{a}}$ \\
\hline & 48 & $10.1^{\mathrm{a}}$ & $10.5^{\mathrm{a}}$ & $11.1^{\mathrm{a}}$ & $10.2^{\mathrm{a}}$ \\
\hline & 72 & $9.6^{\mathrm{c}}$ & $10.2^{\mathrm{b}}$ & $10.7^{\mathrm{a}}$ & $10.3^{\mathrm{b}}$ \\
\hline
\end{tabular}

Eleven buffaloes, one ejaculate per bull; T1: post-final dilution, pre-cooling, T24, 48 and 72-hours post-cooling; Comparisons were made only within line; Different letters indicate $\mathrm{P}<0.05$. TM: total motility; PM: progressive motility; VCL: curvilinear velocity $(\mu \mathrm{m} / \mathrm{s})$; VAP: average path velocity $(\mu \mathrm{m} / \mathrm{s})$; VSL: straight line velocity $(\mu \mathrm{m} / \mathrm{s})$; LIN: linearity (\%); STR: straightness (\%); WOB: oscillation index (\%); ALH: amplitude of lateral head displacement $(\mu \mathrm{m})$ and BCF: beat cross frequency $(\mathrm{Hz})$. 
It was observed that up to 72 hours of incubation, total motility values were maintained above $70 \%$, and progressive motility was close to $50 \%$. Maintaining these motility values for this length of time indicated a good perspective of the use of cooled semen in conventional insemination and FTAI. In another work, using refrigerated $\left(5^{\circ} \mathrm{C}\right)$ buffalo semen in TRIS with $10 \%$ LDL extender, Becerra (2017) reported a TM of 90 and $60 \%$ and PM of 40 and $<30 \%$, at 24 and 48 hours of incubation, respectively. While Almeida et al. (2016), using the same extender, observed a TM of 81.3 and $70.4 \%$ and $\mathrm{PM}$ of 51.2 and $41.8 \%$, at 24 and 48 hours of incubation $\left(5^{\circ} \mathrm{C}\right)$, respectively.

The potential of causing injuries to sperm is lower with cooling (at least in the initial incubation phase) than with freezing (Bucker et al., 2009; Borges-Silva et al., 2015; Almeida et al., 2015, 2016, 2017). Sperm cells submitted to freezing/thawing processes are considered precapacitated due to changes in the sperm membranes (Watson, 1995), and those changes reduce the longevity of the sperm cells post thaw. Reduced longevity of the sperm cells post thaw associated to the difficulties one faces to detect estrous in buffalo (Baruselli et al., 2009) and elect the best moment to perform the insemination are factors which may reduce fertility. Therefore, using cooled semen with a longer lifespan in the genital tract has a better perspective as far as fertility is concerned.

Verstegen et al. (2002) reported that VCL, VAP and VSL values were significantly higher in samples which produce an in vitro fertilization index above 50\%. Still, according to the author, $\mathrm{BCF}$ and LIN parameters have a positive correlation with gestation rate, and are, therefore, able to grant useful information for the use of semen in females (Farrell et al., 1998; Verstegen et al., 2002 and Ahmed et al., 2016).

Kinetic parameters of the sperm cells incubated in four extenders are presented in Table 2. At all assessment times, from the beginning to the end of the incubation period, significant differences were detected among treatments. Two general tendencies can be observed assessing the results altogether considering all evaluation times. Firstly, for most of the kinetics parameters and incubation times, the lowest results belonged to the lower category when the TRIS 5\% LDL extender was used.

The second tendency appeared when TRIS $10 \%$ LDL was used, showing that more frequently results belonged to the upper category. Exception to this tendency was the value obtained for VAP at 72 hours of incubation, which was in the intermediate category. Kinetics parameter values of sperm diluted in TES-TRIS 5 or $10 \%$ LDL varied between the upper and lower categories, being less frequent in the upper category as compared to TRIS $10 \%$ LDL. TES-TRIS extender has skim milk in its composition, which contributes to the cryoprotectant effect of the extender (Hafez and Hafez, 2004). The presence of skim milk in association to LDL may have had a beneficial effect and thus better preserving some spermatic parameters at certain incubation times, in relation to TRIS 5\% of LDL.

On the other hand, TES-TRIS $10 \%$ of LDL did not surpass TRIS $10 \%$ extender, as would be expected. Contrariwise, for several spermatic parameters and at several incubation times, TESTRIS $10 \%$ of LDL extender preserved the quality of sperm movement less efficiently than TRIS 10\% LDL. Thus, a beneficial effect of the association of skim milk with LDL, if any, was not expressed in the TES-TRIS extender with $10 \%$ LDL. This was confirmed by the fact that the ALH value was greater for the TES-TRIS dilutors at different concentrations compared to TRIS $10 \%$ LDL, which indicated that there was greater interference in sperm progressivity. According to Arruda et al. (2002), a greater ALH is characterized by sperm movements which result in higher energy consumption by sperm during dislocation and lower quality of sperm movement. On the other hand, BCF is considered the equivalent to vigor of sperm cells (Contri et al., 2010) and shows the efficiency of the flagellate beat. TRIS $10 \%$ LDL, at all evaluation times, maintained BCF in the upper category when compared to other extenders. Results of functional integrity of sperm membrane assessed by HOST are presented in Table 3. 
Table 3. Effects of different extenders on the integrity of buffalo sperm membrane assessed by the hypoosmotic swelling test (HOST) post dilution (T1 hour) and refrigeration at $5^{\circ} \mathrm{C}(\mathrm{T} 24, \mathrm{~T} 48$ and $\mathrm{T} 72$ hours)

\begin{tabular}{cccccc} 
& & \multicolumn{4}{c}{ Diluents } \\
\cline { 3 - 6 } & Time & TES-TRIS 10\% & TES-TRIS 5\% & TRIS 10\% & TRIS 5\% \\
& (hours) & LDL & LDL & LDL & LDL \\
\hline & 1 & $78.1^{\mathrm{b}}$ & $77.1^{\mathrm{b}}$ & $83.8^{\mathrm{a}}$ & $78.8^{\mathrm{b}}$ \\
HOST (\%) & 24 & $75.5^{\mathrm{a}}$ & $69.6^{\mathrm{b}}$ & $73.6^{\mathrm{ab}}$ & $69.6^{\mathrm{b}}$ \\
& 48 & $64.7^{\mathrm{b}}$ & $64.8^{\mathrm{b}}$ & $68.6^{\mathrm{a}}$ & $66.6^{\mathrm{ab}}$ \\
& 72 & $59.8^{\mathrm{b}}$ & $60.0^{\mathrm{b}}$ & $63.5^{\mathrm{a}}$ & $61.6^{\mathrm{ab}}$ \\
\hline
\end{tabular}

Eleven buffaloes, one ejaculate per donor; T1= post final dilution just precooling; Different letters in the same line indicate $\mathrm{P}<0.05$.

At incubation time 1, the percentages of sperm cells reacting to HOST were elevated for all treatments, nonetheless, it was even higher for the TRIS $10 \%$ LDL extender $(\mathrm{P}<0.05)$. This indicates that in the beginning of the incubation period the functional integrity of the sperm membrane was high. During the whole incubation period, TRIS $10 \%$ LDL extender maintained the integrity of the sperm membrane at a higher level. The sperm cells maintained in the TES-TRIS medium, either with 5 or $10 \%$ LDL, presented a lower proportion of reactive cells than that found in TRIS $10 \%$, except for the $24 \mathrm{~h}$ incubation time. On the other hand, the incidence of reactivity to HOST was similar for sperm cells diluted in TRIS $10 \%$ or $5 \%$. Similar behaviour of cooled buffalo sperm cells $\left(5^{\circ} \mathrm{C}\right)$ was reported by Becerra (2017), who observed that $74.7 \%$ of the cells diluted in TRIS $10 \%$ LDL reacted too HOST at 48 hours of incubation. Akhter et al. (2011) comparing the efficacy of LDL in replacement of whole egg yolk found that for buffalo frozen semen 10\% LDL was more efficient than $2.5,5,15 \%$ of LDL or $20 \%$ of whole egg yolk.

LDLs are the major components of whole egg yolk and are the components which confer cryoprotection to sperm cells. The cryoprotective mechanism of LDL is through binding seminal plasma proteins (BSPs) forming an inactive stable complex (LSL-BSP) Free BSPs destabilize sperm membrane by inducing efflux of cholesterol (Manjunath et al., 2002) leading to a shortening of the sperm cell longevity.

The TES-TRIS extender has in its constitution skimmed milk (Vale et al., 1984). Milk is a biological product with a complex composition including proteins, salts, glycides, lipids, vitamins, among others (Pelczar et al., 1996). Bergeron et al. (2007), reported that the protein fraction, mainly casein, confers a protective effect over sperm by a mechanism similar to that described for LDLs. Despite both LDLs and milk protected sperm cells against cryo-damages through a similar mechanism and that both were present in TES-TRIS extenders, in those extenders no additive cell protection effect to cooling was observed in the present study. On the contrary, at most assessment times parameters of sperm cells were inferior to those found when TRIS 10\% LDL was used.

Although the fertilization potential of semen through laboratory evaluation is still to be assessed, the evaluation of the sperm viability expressed by good motility is a expressive predictor of fertility tests in vitro or in vivo (Ahmed et al., 2016, Boccia et al., 2007, Verstegen et al., 2002).

\section{CONCLUSIONS}

Based on the evolution of the kinetics parameters and the membrane integrity of buffalo sperm cells along 72 hours of incubation at $5^{\circ} \mathrm{C}$, it can be concluded that all extenders tested are candidates for cooling semen. However, on the whole, TRIS 10\% LDL appears to be the best one to be used in artificial insemination.

\section{ACKNOWLEDGEMENTS}

Thanks are due to the INCT da Pecuária CNPq/FAPEMIG for their financial support and to the Coordenação de Aperfeiçoamento de Pessoal de Nível Superior (CAPES) for granting a scholarship. 


\section{REFERENCES}

AHMED, H.; ANDRABI, S.M.H.; ANWAR, M. et al. Use of post-thaw semen quality parameters to predict fertility of water buffalo (Bubalus bubalis) bull during peak breeding season. Andrologia, v.20, p.1-6, 2016.

AKHTER, S.; ANSARI, M.S.; RAKHA, B.A. et al. Effect of low density lipoproteins in extender on freezability and fertility of buffalo (Bubalus bubalis) bull semen. Theriogenology, v.76, p.759-764, 2011.

ALMEIDA, J.; BRITO, M.F.; BECERRA, V.A.B. et al. Evaluation of the pregnancy rates in primiparous buffaloes submitted to FTAI with refrigerated semen $v s$. frozen during the unfavorable breeding station. In: ANNUAL MEETING OF THE BRAZILIAN EMBRYO TECHNOLOGY SOCIETY, 31., 2017, Cabo de Santo Agostinho. Proceedings... Cabo de Santo Agostinho, PE, SBTE, 2017. Abstracts. A022, Animal Reproduction.

ALMEIDA, J.; NEVES, B.P.; BRITO, M.F. et al. Pregnancy rates of buffaloes (Bubalus bubalis) using cooled or frozen semen at fixed time artificial insemination (FTAI) - Preliminary results. In: CONGRESSO MUNDIAL DE BÚFALOS, 11., 2016, Cartagena. Anais... Cartagena, Colômbia: Medicina Veterinaria y Zootecnia, 2016.

ALMEIDA, J.; BRITO, M.F.; AULER, P.A. et al. Avaliação das taxas de prenhez em búfalas com o uso de sêmen refrigerado vs. congelado em programas de IATF durante a estação reprodutiva desfavorável. In: CONGRESSO BRASILEIRO DE REPRODUÇÃO ANIMAL, 21., 2015, Belo Horizonte, MG. Anais... Belo Horizonte: CBRA, 2015. p.99.

ARRUDA，R.P.; BALL，B.A.; GRAVANCE, C.G. et al. Effects of extenders and cryoprotectants on stallion sperm head morphometry. Theriogenology, v.58, p.253-256, 2002.

BARUSELLI, P.S.; CARVALHO, N.A.T.; JACOMINI, J.O. Eficiência uso da inseminação artificial em búfalos. Rev. Bras. Reprod. Anim. Supl., p.104-110, 2009.
BECERRA, V.A.B. Efeito da adição de Aniba canelilla, blueberry e polifenol de chá verde sobre a viabilidade in vitro de espermatozoides de búfalo (Bubalus bubalis) resfriados a $5^{\circ} \mathrm{C}$. 2017. 69f. Dissertação (Mestrado) - Escola de Veterinária, Universidade Federal de Minas Gerais, Belo Horizonte, MG.

BERGERON, A.; BRINDLE, Y.; BLONDIN, P. et al. Milk caseins decrease the binding of the major bovine seminal plasma proteins to sperm and prevent lipid loss from the sperm membrane during sperm storage. Biol. Reprod., v.77, p.120126, 2007.

BOCCIA, L.; DI PALO, R.; DE ROSA, A. et al. Evaluation of buffalo semen by Trypan blue/Giemsa staining and related fertility in vitro. Ital. J. Anim. Sci., v.6, Suppl.2, p.739-742, 2007.

BORGES-SILVA, J.C.; SILVA, M.R.; MARINHO, D.B. et al. Cooled semen for fixedtime artificial insemination in beef cattle. Reprod. Fertil. Dev., v.28, p.1004-1008, 2015.

BUCHER, A.; KASIMANICKAM, R.; HALL, J.B. et al. Fixed-time AI pregnancy rate following insemination with frozen-thawed or fresh-extended semen in progesterone supplemented CO-Synch protocol in beef cows. Theriogenology, v.71, p.1180-1185, 2009.

CONTRI, A.; VALORZ, C.; FAUSTINI, M. et al. Effect of semen preparation on casa motility results in cryopreserved bull spermatozoa. Theriogenology, Philadelphia, v.74, p.424-435, 2010.

FARRELL, P.B.; PRESICCE, G.A.; BROCKETT, C.C. et al. Quantification of bull sperm characteristics measured by computerassisted sperm analysis (CASA) and the relationship to fertility. Theriogenology, v.49, p.871-879, 1998.

HAFEZ, E.S.E.; HAFEZ, B. Espermatozoides e plasma seminal: reprodução animal. 7ed. São Paulo: Manole, 2004. p.97-110.

HOLT, W.V. Basic aspects of frozen storage of semen. Anim. Reprod. Sci., v.62, p.3-22, 2000.

INSTITUTO Brasileiro de Geografia e Estatística. Available in: <http://www.ibge.gov.br/home>. Accessed in: December 12, 2013. 
MANJUNATH, P.; NAUC, V.; BERGERON, A. et al. Major proteins of bovine seminal plasma bind to the low-density lipoprotein fraction of hen's egg yolk. Biol. Reprod., v.67, p.1250-1258, 2002.

MANUAL for andrological examination and evaluation of animal semen. 3.ed. Belo Horizonte: Brazilian College of Animal Reproduction, 2013. 104p.

NEVES, M.M. Extração das lipoproteínas de baixa densidade da gema do ovo de Gallus domesticus e sua aplicação na criopreservação do sêmen canino. 2008. 116f. Tese (Doutorado em Ciência Animal) - Escola de Veterinária, Universidade Federal de Minas Gerais, Belo Horizonte, MG.

PELCZAR, M.J.; CHANG, E.C.S.; KRIEG, N.R. Microbiologia: conceitos e aplicações. 2.ed. São Paulo: Makron Books, 1996. v.2, 600p.

SINGH, A.K.; SINGH, V.K.; NARWADE, B.M. et al. Comparative quality assessment of bubalo (Bubalus bubalis) semen chilled $\left(5^{\circ} \mathrm{C}\right)$ in egg yolk- and soya milk-based extenders. Reprod. Domest. Anim., v.47, p.596-600, 2012.
STATA: release 12. Statistical software. College Station, Texas: StataCorp LP, 2012.

VALE, W.G.; RIBEIRO, H.F.L.; SOUSA, J.S. et al. Inseminação artificial em búfalos (Bubalus bubalis) na Região Amazônica. In: CONGRESSO BRASILEIRO DE MEDICINA VETERINÁRIA, 21., 1984, Belém. Anais... Belém: Sociedade Brasileira de Medicina Veterinária, 1984. v.1, p.91.

VERSTEGEN, J.; IGUER-OUADA, M.; OCLIN, K. Computer assisted semen analyzers in andrology research and veterinary pratice. Theriogenology, v.57, p.149-179, 2002.

VISHWANATH, R. Artificial insemination: the state of the art. Theriogenology, v.59, p.571-584, 2003.

WATSON, P.F. Recent development and concepts in the cryopreservation of spermatozoa and the assessment of their post-thawing function. Reprod. Fertil. Dev., v.7, p.871-891, 1995.

YANAGIMACHI, R. Mammalian fertilization. In: KNOBIL, E.; NEILL, J. (Eds.). The physiology of reproduction. 2.ed. New York: Raven Press, 1994. p.189-317. 